Ekonomia - Wroclaw Economic Review 24/3 (2018)

Acta Universitatis Wratislaviensis

No 3881

DOI: 10.19195/2084-4093.24.3.4

\author{
Anna Brdulak \\ ORCID: 0000-0001-7881-1303 \\ Wyższa Szkoła Bankowa we Wrocławiu \\ anna.brdulak@wsb.wroclaw.pl
}

\title{
Znaczenie innowacji technologicznych dla podnoszenia poziomu jakości życia mieszkańców miast - wybrane przykłady rozwiązań w polskich start-upach
}

Artykuł nadesłany: 3 lipca 2018 r.; artykuł zaakceptowany: 4 września 2018 r.

JEL Classification: M13, O35, Q01

Keywords: start-up, innovative business, city, quality of life, technologies

\begin{abstract}
The importance of technological innovations in raising the quality of life of city dwellers: Selected examples of solutions in Polish start-ups

The main goal of the study is to analyze technological solutions offered by start-ups, designed to improve the living standards of city dwellers. The text consists of two parts, theoretical and practical. In theoretical considerations, the author relies on selected literature items. The review of secondary sources first of all serves to define the concept of start-up, and then to expand and enrich the practical part with additional technological solutions for the described projects and this role is directly related to the purpose of the presented article. In the practical part, selected case studies were described and analyzed with reference to the results of the author's own research. The research project was carried out by the author in 2016-2017 in cooperation with the Wroclaw Agglomeration Development Agency. Its aim was to analyze the start-up ecosystem in Wroclaw and to try to find an answer to the question about the importance of start-ups for the quality of life of city dwellers. Recommendations for the local authorities in Wroclaw on how to support ventures in entering the market and remaining there were of additional value. The project consisted of three parts. The first two were analyses of secondary sources, on the basis of which the necessary information was collected related to the definition of a start-up company and the current situation of enterprises in Poland and Wroclaw, and quantitative research in the form of an online survey on a sample of $n=108$ start-ups from Wroclaw. The last stage of the research project was the qualitative part. It was in the form of individual
\end{abstract}


interviews with start-ups and industry experts. Seven respondents took part in this component of the study. The result of the research was a characterization of the start-up environment in Wroclaw. Answers to the questions asked in the questionnaire, supplemented by expert interviews, allowed to determine, among others, the branches in which Wroclaw start-ups operate, to identify the products offered by them and to extrapolate the results of start-ups' situation to the whole of Poland. Based on the obtained knowledge, it was possible to present the importance of technological solutions of individual start-ups for the quality of life of city dwellers. According to the results of own research and the analysis of secondary sources, it can be stated that the presence of startups in urban space improves the quality of life of city dwellers, while also supporting the construction of social capital.

\section{Wstęp}

Główny cel pracy i jednocześnie problem naukowy stanowi analiza rozwiązań technologicznych oferowanych przez wybrane polskie start-upy, mających na celu poprawę jakości życia mieszkańców miast. Podmiotem badań przeprowadzonych w 2017 roku we współpracy z Agencją Rozwoju Aglomeracji Wrocławskiej w ramach grantu badawczego Mozart, przyznawanego przez Urząd Miasta, jest grupa start-upów $\mathrm{z}$ Wrocławia w liczbie $\mathrm{n}=108$ oraz siedmiu ekspertów branży. Zadaniem pierwszej części — ilościowej — jest dostarczenie ogólnej wiedzy na temat start-upów we Wrocławiu. Druga część — jakościowa - ma charakter eksploracyjny. Sposób podejścia do badań powoduje, iż autorka rezygnuje z hipotez na rzecz następujących pytań badawczych:

1. Co start-upy dają miastu? Na co mają wpływ?

2. Czy start-upy wpływają na jakość życia mieszkańców? W jaki sposób i dlaczego?

Przeprowadzone badania wykorzystują metodę studium przypadku opierającego się zarówno na pogłębionym wywiadzie indywidualnym przy użyciu kwestionariusza, jak i na analizie ilościowych wyników badań pierwotnych oraz źródeł wtórnych w postaci raportów, danych statystycznych i innych opracowań.

\section{Teoretyczny aspekt badań}

Obecnie na świecie, a także w Polsce, zaczyna powstawać coraz więcej przedsięwzięć nazywanych start-upami, których rozwiązania mogą (choć nie muszą) wprowadzać innowacje przełomowe w różnych dziedzinach. Są one postrzegane jako motor rozwoju gospodarczego. Według prognoz Deloitte w 2023 roku wartość dodana wygenerowana przez start-upy może wynieść 2,2 mld zł (Diagnoza ekosystemu startupów w Polsce, 2016). Jest to związane z rolą, jaką ogólnie odgrywają innowacje w budowaniu konkurencyjności gospodarki. Przy takim założeniu siła gospodarki w długim okresie będzie zależeć od dwóch kluczowych czynników - liczby (czyli skali rozwoju) start-upów i odsetka firm, które odniosły sukces rynkowy. Przyjmując powyższą klasyfikację gospodarek, najsilniejszą 
jest ta, która przy dużej liczbie start-upów ma jednocześnie wysoki wskaźnik osiągania przez nie sukcesu. Takimi krajami są między innymi Stany Zjednoczone czy Izrael (Global Startup Ecosystem Report 2017, 2017). Rolę, jaką odgrywają Stany Zjednoczone w tworzeniu start-upów, potwierdzają wyniki najnowszego raportu KPMG, Venture Pulse Q1 2018. Global analysis of venture funding (2018). Według danych w pierwszym kwartale 2018 roku kraj ten był najważniejszym rynkiem dla funduszy inwestycyjnych venture capital (VC). Ponad 61\% światowych inwestycji VC w start-upy (ponad 30 mld dolarów) trafiło do Stanów.

$\mathrm{W}$ prezentowanym artykule oraz przeprowadzonych przez autorkę badaniach start-up definiowany jest jako niewielki podmiot rynkowy (nie zawsze musi to być firma w sensie komercyjnego działania) funkcjonujący przede wszystkim (lecz nie wyłącznie) w obszarze nowych technologii.

Powyższą definicję uzupełnia podejście E. Riesa, jednej z głównych postaci w branży start-upowej. Określa on start-up jako firmę, która oferuje innowacyjny produkt (towar lub usługę) na rynku w warunkach skrajnej niepewności. Podejście to jest szczegółowo opisane w podręczniku The Lean Start-up. How Today's Entrepreneurs Use Continuous Innovation to Create Radically Successful Businesses uznanym przez „New York Times” za kluczowy w rozumieniu zjawiska start-upu (Ries, 2012).

W porównaniu do innych podmiotów start-up będzie się odznaczać wyższym poziomem ryzyka, głównie z uwagi na funkcjonowanie w sferze innowacji technologicznych. Wyższe ryzyko związane jest zazwyczaj z wyższym uzyskiwanym, w wypadku odniesienia sukcesu przedsiębiorstwa, zwrotem z inwestycji.

Startupy odgrywają kluczową rolę w procesach innowacyjnych (Colombo, Piva, 2008; Davila et al., 2003; Mustar et al., 2008). Zgodnie z definicją Steve'a Blanka (Blank; 2010) start-up jest firmą, spółką lub tymczasową organizacją, której celem jest poszukiwanie powtarzalnego i skalowalnego modelu biznesowego. W fazie rozruchu nowe pomysły są wprowadzane na rynek i przekształcane w ekonomicznie zrównoważone przedsiębiorstwa. Nowe firmy to artefakty służące przekształcaniu przedsiębiorczego osądu w zysk (Spender, 2014). Istniejące badania wskazują, że tworzenie sieci relacji z partnerami zewnętrznymi stanowi jeden z priorytetów dla osiągnięcia sukcesu przez start-up (Teece, 2010; Pangarkar, Wu, 2012; Kask, Linton, 2013).

Start-upy odgrywają również ważną rolę w procesach rozwoju miasta. Ich rozwiązania, w większości oparte na innowacjach technologicznych (Blank, 2013), poprawiają jakość życia mieszkańców i uatrakcyjniają przestrzeń miejską.

W tym miejscu należy przybliżyć znaczenie pojęcia innowacji technologicznych. Według literatury można wyróżnić innowacje produktowe, czyli wprowadzanie do produkcji nowych wyrobów i usług, oraz innowacje procesowe oznaczające zastosowanie nowych sposobów uzyskiwania tych samych wyrobów (Drucker, 1992; Schumpeter, 1995). Innowacje technologiczne powstają wskutek działalności innowacyjnej obejmującej wiele działań o charakterze badawczym 
(naukowym), technicznym, organizacyjnym, finansowym i handlowym (Słownik portalu Prawo Podatkowe, 2018).

W dalszej części pracy autorka skupi się na opisie wybranych start-upów oferujących rozwiązania $\mathrm{z}$ wykorzystaniem innowacji technologicznych w celu podnoszenia jakości życia mieszkańców miast.

\section{Metodologia badań}

Prezentowane w artykule dane otrzymane zostały w wyniku analizy źródeł wtórnych (bieżące raporty, literatura) oraz przeprowadzonego przez autorkę projektu badawczego podzielonego na trzy etapy. Pierwszy z nich stanowiło zebranie i analiza dostępnych danych ze źródeł wtórnych (desk research). Na ich podstawie, w ramach drugiego etapu projektu, została opracowana i przeprowadzona ankieta ilościowa skierowana do start-upów. Trzecim etapem były badania jakościowe w postaci indywidualnych wywiadów pogłębionych.

Celem ankiety ilościowej była możliwie jak najdokładniejsza charakterystyka środowiska start-upowego we Wrocławiu. Stąd też pojawiły się pytania o rok zarejestrowania, zatrudnienie czy branżę.

Uzupełnieniem statystyk był wspomniany wywiad indywidualny. Moduły jakościowe badania służą do uzyskania informacji na tematy dotąd rozpoznane w niewielkim stopniu. Badania jakościowe są próbą uchwycenia ukrytego sensu, który strukturyzuje to, co mówimy, i to, co faktycznie robimy, a także eksploracją, dookreślaniem i systematyzacją prawdziwego znaczenia odkrytego zjawiska społecznego (Banister et al., 1994). Jest to niezwykle istotne w przypadku chęci dotarcia do znaczenia start-upów dla jakości życia mieszkańców miast czy określenia rzeczywistych potrzeb i oczekiwań start-upowców względem miasta.

Zarówno część ilościowa, jak i jakościowa miały oddzielne, ściśle przypisane funkcje. Badanie ilościowe opierało się na ankiecie składającej się z szesnastu pytań głównych. W wypadku niektórych z nich, po udzieleniu twierdzącej odpowiedzi, respondent był proszony o doprecyzowanie lub dodatkową wypowiedź.

Respondenci byli rekrutowani za pomocą pięciu kanałów:

1. utworzone wydarzenie na Facebooku (FB),

2. mailing,

3. kontakt bezpośredni,

4. przy okazji wybranego wydarzenia - w tym wypadku konferencji poświęconej start-upom, Start-up Wrocław: Ewolucje w listopadzie 2016,

5. strona internetowa www.wroclaw.pl.

W rekrutacji grupy docelowej zastosowano metodę kuli śnieżnej. Metoda ta stosowana jest, gdy trudno dotrzeć do członków badanej populacji, i polega na tym, że badacz odszukuje kilku członków badanej populacji, a następnie prosi ich o nawiązanie kontaktu ze znajomymi, którzy także należą do badanej populacji 
(Babbie, 2007). W przeprowadzonym badaniu bezpośrednio po rekrutacji respondenci byli sprawdzani pod kątem zgodności z przyjętym opisem badanej grupy.

Ostatecznie w badaniu wzięło udział $\mathrm{n}=108$ start-upów z Wrocławia zarówno zarejestrowanych, jak i funkcjonujących na rynku bez rejestracji. Warto zwrócić uwagę, że różnica pomiędzy całkowitą liczbą respondentów, a poszczególnymi liczebnościami w odpowiedziach na pytania na przykład o miejsce zarejestrowania czy siedzibę firmy wynika $\mathrm{z}$ faktu, iż do badania dopuszczone zostały również start-upy, które już funkcjonują, jednak jeszcze nie zarejestrowały swojej działalności.

Istotną trudność w określeniu próby badawczej było zdefiniowanie grupy docelowej. Ponieważ pojęcie organizacji start-upu nie jest jednoznacznie zdefiniowane, przyjęto podejście E. Riesa, autorytetu dla branży start-upowej. Szczegółowy opis owego podejścia został przedstawiony dalej.

W części jakościowej badania przeprowadzono wywiady pogłębione z siedmioma ekspertami branży i start-upowcami związanymi ze środowiskiem wrocławskim, lecz działającymi na skalę ogólnopolską. Wybór rozmówców podyktowany był zarówno ich proaktywną postawą w branży start-upowej, jak też pełnioną przez nich funkcją mentorów oraz autorytetów dla innych przedstawicieli analizowanych przedsięwzięć w całym kraju.

W opracowaniu autorka odwołała się do wyników badań własnych ilościowych i jakościowych oraz, szczególnie przy formułowaniu wniosków i ekstrapolacji wyników na skalę ogólnopolską, do aktualnych źródeł wtórnych.

\section{Technologie jako wiodący typ działalności start-upów we Wrocławiu}

W niniejszym artykule podjęto rozważania związane z analizą poszczególnych rozwiązań oferowanych przez opisywane przedsięwzięcia w kontekście podnoszenia jakości życia mieszkańców miast. Podstawą takiego założenia był fakt, że autorskie badanie wrocławskich start-upów potwierdziło, iż technologie są wiodącym typem działalności wspomnianych podmiotów (59\% odpowiedzi na pytanie: „Jaki jest wiodący typ działalność start-upu?”). Są to przede wszystkim: usługi związane z obsługą stron internetowych (36\%), aplikacje (20\%) i ICT (3\%). Na drugim miejscu znalazła się szeroko rozumiana działalność usługowa - 27\%. Wśród pojedynczych wskazań innych typów funkcjonowania pojawiły się laboratorium badawczo-rozwojowe, produkcja gier, telemedycyna oraz digital learning. Wśród odpowiedzi dotyczących branży, w jakiej działają start-upy dominuje odpowiedź: „inna” (47\% wskazań). Pod tym pojęciem rozumie się przede wszystkim obszary związane z technologiami, między innymi nanotechnologie, aplikacje usługowe, platformy biznesowe, oprogramowanie/gry komputerowe, urządzenia elektroniczne, biotechnologia, produkty (zestawy diagnostyczne) i usługi (z za- 
kresu diagnostyki) w obszarze ochrony zdrowia, weterynarii, jakości żywności i produktów farmaceutycznych czy internet rzeczy - smart home, modelowanie CAD i druk 3D, elektronika użytkowa, technologie/fotografia, wyspecjalizowana inżynieria mechaniczna i budowlana czy produkcja wypełniaczy technologicznych (Brdulak, 2017).

W kontekście przeprowadzonych przez autorkę badań w dalszej części tekstu w pierwszej kolejności zaprezentowano rozwiązania technologiczne oferowane przez dwa wrocławskie start-upy. Opisy te uzupełniono przykładami ogólnopolskich przedsięwzięć, których proponowane rozwiązania mają na celu poprawę jakości życia mieszkańców miast. Analizowane start-upy z innych rejonów Polski zostały wybrane na podstawie rozmów z ekspertami branży.

\subsection{Wybrane przykłady innowacyjnych technologii stosowanych przez polskie start-upy}

Jednym z wrocławskich start-upów, którego produkt w formie aplikacji wspiera kierowców w szybkim znajdowaniu wolnych miejsc do parkowania i efektywnym do nich dotarciu, jest Touch\&Park. Aplikacja rozwiązuje problem zatłoczonych ulic miasta należącego do najbardziej zakorkowanych w Polsce. Pozwala ona na szybsze i efektywniejsze parkowanie, szczególnie w zatłoczonych lub dużych obszarach przeznaczonych do postoju pojazdów. System nie tylko znajduje wolne miejsce dzięki specjalemu algorytmowi, który wskazuje najszybszą, lecz niekoniecznie najkrótszą, drogę do parkingu. $Z$ jego pomocą można również zarezerwować miejsce w podanym obszarze czy opłacić postój. Użytkowanie nie jest skomplikowane. Trzeba przycisnąć jeden przycisk, żeby znaleźć najlepsze miejsce do zaparkowania. W przyszłości twórcy chcą rozbudować technologię, integrując system z systemem ITS, co znacząco zwiększyłoby sprawność ruchu miejskiego. Tym, co wyróżnia produkt Touch\&Park spośród innych podobnych, jest odporność na warunki atmosferyczne oraz niekonieczność konserwacji sensorów. System doładowuje energia słoneczna. W przypadku niewystarczającej ilości słońca zapas energii w module wystarcza na blisko dwa lata.

Dzięki technologii oferowanej przez start-up możliwe jest uniknięcie niepotrzebnego ruchu generowanego przez kierowców szukających wolnych miejsc. Tym samym spada też zużycie paliwa i następuje redukcja smogu. Korzystanie z aplikacji sprawia, że maleje frustracja wśród jej użytkowników, a to z kolei wpływa na ogólną poprawę jakości przemieszczania.

Inny start-up z Wrocławia, Areal, postawił na promocję miasta zarówno wśród jego mieszkańców, jak i przyjezdnych. Innowacyjna technologia służy do wzbudzenia zainteresowania miastem i lepszego poznania jego historii. Aplikacja zajęła trzecie miejsce w konkursie Futu Wro Miasto Przyszłości/Laboratorium Wrocław. Areal skorzystał z technologii zastosowanych między innymi w Po- 
kemon Go. Dają one możliwość interakcji z przestrzenią Wrocławia, zabierają mieszkańców na spacer ulicami miasta i pozwalają im na nowo odkryć ważne dla historii i ducha miasta budynki. Posiadacze aplikacji mogą odwiedzić również wirtualną galerię ARteria z pracami wybranych artystów. Dzięki wykorzystaniu technologii rzeczywistości rozszerzonej praktycznie każdy element przestrzeni może stać się elementem wywołującym aplikację.

Aplikacja AReal skierowana jest do miast i instytucji publicznych, jak również prywatnych podmiotów, które planują jej wykorzystanie w promocji własnego produktu (na przykład deweloperzy, biura architektoniczne, galerie, firmy organizujące festiwale; https://www.wroclaw.pl/startupy).

Patrząc z perspektywy ogólnopolskiej, warto zwrócić uwagę na dwa start-upy oferujące rozwiązania w dziedzinie ochrony środowiska: Airly z Krakowa i Handerek Technologies z Warszawy,

Pierwszy z nich stworzył technologię pozwalającą na kontrolę czystości powietrza. Firma (w osobie założyciela Wiktora Warchałowskiego) została finalistą New Europe - konkursu organizowanego przez Google i „Financial Times”, którego celem jest wyłonienie setki najbardziej innowacyjnych osób w Europie Środkowo-Wschodniej.

Start-up w styczniu 2017 roku otrzymał pożyczkę w ramach Funduszu Pożyczkowego Wspierania Innowacji Polskiej Agencji Rozwoju Przedsiębiorczości na budowę sieci sensorów jakości powietrza. Podstawowym założeniem Airly jest poprawa świadomości zagrożenia związanego z zanieczyszczeniem powietrza. W tym celu start-up stworzył skalibrowany metodami AI system dostarczania informacji o zanieczyszczeniu powietrza. Jego podstawę stanowią inteligentne, skomunikowane sensory, które monitorują jakość powietrza w czasie rzeczywistym. Przyjęty proces technologiczny pozwala na efektywne i tanie produkowanie urządzeń o jakości porównywalnej do pyłomierzy przenośnych w cenie około 20 tys. zł czy też bardziej zaawansowanych stacji badawczych (koszt jednej to około $1,5 \mathrm{mln}$ zł), jak również ich prosty montaż w miejscach publicznych. Takie zestawienie umożliwia zbudowanie gęstej sieci urządzeń gromadzących dane dotyczące jakości powietrza oraz autokalibrację systemu (Bagiński, 2017).

Innym interesującym przykładem jest Handerek Technologies z Warszawy. Start-up, założony przez Adama Hańderka wygrał Startup Challenge na European Startup Days 2018 w kategorii „ochrona środowiska”. Stworzona technologia w niskociśnieniowym procesie przekształca nieprzetwarzalne odpady plastikowe w całkowicie rafinowane frakcje oleju napędowego i benzyny. Produkt warszawskiego start-upu to jedno z możliwych rozwiązań problemu coraz większej ilości powstających odpadów. Może on wpłynąć na poprawę sytuacji ekologicznej w skali globalnej.

$\mathrm{W}$ podobnej branży związanej z gospodarką odpadami funkcjonuje firma EcoBins ze Szczecina, która we wrześniu 2015 roku na Targach EKO Kołobrzeg 
zdobyła drugie miejsce w kategorii Eko-Innowacja 2015. Stworzyła ona usługę wykorzystującą Internet Rzeczy (IoT) w celu lepszej kontroli i zarządzania procesem oczyszczania miasta. Firma w pojemnikach na odpady montuje czujniki, które z określoną częstotliwością mierzą poziom ich wypełnienia. W zależności od modelu czujniki badają aktualne położenie, odchylenie od pionu oraz temperaturę wewnątrz pojemnika. Zebrane dane, po odpowiednim przetworzeniu przez oprogramowanie znajdujące się $\mathrm{w}$ chmurze, przesyłane są przez czujniki do serwera centralnego. Następnie po uporządkowaniu trafiają do użytkowników portalu EcoBins oraz aplikacji mobilnej. Połączenie z internetem uzyskiwane jest z wykorzystaniem lokalnej sieci komórkowej. Monitoring stopnia wypełnienia pojemników redukuje liczbę tak zwanych pustych przejazdów pojazdów wywożących odpady. Tym samym zmniejszeniu ulegają również ilość spalin oraz hałas powstały przy opróżnianiu pojemników, co wpływa na lepszą jakość życia lokalnych społeczności (Ecobins, https://mamstartup.pl/startupy/1060/ecobins).

Dbałością o odpowiednią jakość życia wykazuje się też firma Sense monitoring z Sanoka. Oferowana przez nią technologia umożliwia kontrolę bezpieczeństwa konstrukcji dachowych w budynkach magazynowych, halach produkcyjnych i handlowych, w szczególności drożności wpustów, warstw izolacji, a przede wszystkim ciężaru zalegającego śniegu. Dzięki sieci sensorów laserowych dokonujących pomiaru aktualnych ugięć wyznaczonych elementów konstrukcji specjalny algorytm na bieżąco zbiera i przetwarza dane, informując użytkownika za pomocą e-maila i SMS-a o występującym zagrożeniu. Według szacunków firmy Sense monitoring eliminacja ręcznych pomiarów konstrukcji oraz bardziej efektywne odśnieżanie może zredukować koszty utrzymania dachu nawet o 40\%, co byłoby dodatkowym argumentem, oprócz bezpieczeństwa, przemawiającym za wdrożeniem systemu (http://sense-monitoring.com/).

Warto również wspomnieć o start-upie, którego produkty dają możliwość rozwiązania najczęstszych problemów transportowych. Jednym z interesujących przykładów jest system inteligentnych znaków drogowych InZnak, stworzony w ramach współpracy naukowców z Akademii Górniczo-Hutniczej oraz Politechniki Gdańskiej. Jest to pierwsze tego typu rozwiązanie w Polsce i jedno z niewielu na świecie.

Podstawowym celem projektu jest poprawa bezpieczeństwa przemieszczania się po drogach publicznych. W tym celu został stworzony nowy rodzaj inteligentnych znaków drogowych (znaki stojące, wiszące i mobilne wyświetlające dynamicznie aktualizowaną zalecaną prędkość jazdy określaną samoczynnie), które umożliwią zapobieganie najpowszechniejszym kolizjom na drogach szybkiego ruchu. Należy podkreślić, że InZnak jest systemem dynamicznym. Nie tylko dostosowuje się do warunków panujących na drodze, lecz także na bieżąco analizuje otoczenie i informuje kierowców na przykład o konieczności hamowania. Wdrożenie projektu planowane jest na 2021 rok (Trębacz, 2018). 


\section{Wnioski}

W artykule opisano wybrane polskie start-upy, których produkty, będące innowacyjnymi technologiami, wspierają jakość życia mieszkańców miast. Wspomniane rozwiązania zostały pogrupowane ze względu na lokalizację oraz funkcjonalność produktu. Z uwagi na badania własne autorki w pierwszej kolejności opisano dwa wrocławskie start-upy: Touch \& Park, oferujący rozwiązania w obszarze transportu, oraz Areal, posiadający aplikację pomagającą promować i jednocześnie uatrakcyjnić miejsce, w którym żyje określona społeczność lokalna. Kolejne trzy przedsięwzięcia, Airly z Krakowa, Handerek Technology z Warszawy i EcoBins ze Szczecina, działają w obszarze ochrony środowiska. Firma Sense Monitoring to start-up z Sanoka oferujący produkt wspierający monitoring bezpieczeństwa ludzi podczas pracy. Ostatni opisywany start-up, InZnak (partnerstwo naukowców z Krakowa i Gdańska), to podmiot oferujący, podobnie jak wrocławski Touch\&Park, rozwiązanie w obszarze transportu.

W podsumowaniu warto podkreślić, że w przypadku oferowanych produktów technologia odgrywa drugorzędną rolę. Na pierwszym miejscu należy uwzględnić problemy, z jakimi mierzą się mieszkańcy rozwijających się miast, oraz związane z nimi oczekiwania poszczególnych grup społeczności lokalnych.

Analizując znaczenie innowacji technologicznych dla podnoszenia poziomu jakości życia mieszkańców miast, w istocie należy uwzględnić cały mechanizm społeczny, na którym opiera się rozwój miasta. Należą do niego przyjazne środowisko, w tym czyste powietrze, dostęp zieleni miejskiej, w tym do skwerów i parków, bezpieczne miejsca pracy, przyjazny i otwarty na mieszkańca urząd czy też wybrane udogodnienia, z których na co dzień mogą korzystać obywatele, świadczące o atrakcyjności danego miejsca. Innowacyjne technologie, oferowane przez opisywane polskie start-upy, wpasowują się w wybrane obszary rozwoju miast, pełniąc ważną rolę w podwyższaniu poziomu jakości życia jego mieszkańców.

\section{Bibliografia}

\section{Literatura}

Babbie E. (2007), Conducting qualitative field research, [w:] E. Babbie, The Practice of Social Research (11th ed.), Belmont.

Banister P., Burman E., Parker I., Taylor M., Tindall C. (1995), Qualitative Methods in Psychology: A Research Guide, Buckingham.

Blank S. (2013), Why the Lean Start-Up Changes Everything, „Harvard Business Review”, May.

Colombo M.G., Piva E. (2008), Strengths and weaknesses of academic start-ups: A conceptual model, „IEEE Transactions on Engineering Management” 55(1), s. 37-49. 
Davila A., Foster G. \& Gupta M. (2003), Venture capital financing and the growth of start-up firms, „Journal of Business Venturing” 18, s. 689-709.

Drucker, P.F. (1992), Innowacja i przedsiębiorczość. Praktyka i zasady., Warszawa.

Kask J., Linton G. (2013), Business mating: when start-ups get it right, „Journal of Small Business \& Entrepreneurship" 26(5), s. 511-536.

Mustar P., Wright M., Clarysse B. (2008), University spin-off firms: lessons from ten years of experience in Europe, ,Science and Public Policy” 35(2), s. 67-80.

Pangarkar N., Wu J. (2012), Industry globalization and the performance of emerging market firms: Evidence from China, „International Business Review” 21(2), s. 196-209.

Ries E. (2012), The Lean Start-up. How Today's Entrepreneurs Use Continuous Innovation to Create Radically Successful Businesses, Crown Publishing Group, Division of Random House Inc.

Schumpeter J.A. (1995), Kapitalizm, socjalizm, demokracja, Warszawa.

Spender J.C. (2014), Business strategy: Managing uncertainty, opportunity, and enterprise, Oxford. Teece D.J. (2010), Business Models, Business Strategy and Innovation, „Long Range Planning” 43(2-3), s. 172-194.

\section{Raporty}

Brdulak A. (2017), Raport z badania wpływu startupów na jakość życia mieszkańców miast. Analiza ekosystemu startupów we Wrocławiu - raport nieopublikowany.

Diagnoza ekosystemu startupów w Polsce (2016), raport Deloitte, Warszawa.

Global Startup Ecosystem Report 2017 (2017), Startup Genome, Oakland CA, USA.

Venture Pulse Q1 2018. Global analysis of venture funding (2018), raport KPMG, Warszawa.

\section{Źródła internetowe}

Bagiński K. (23.11.2017), Polska firma zrobiła to, czego Morawiecki nie potrafit. Ich technologia pomaga walczyć ze smogiem, http://innpoland.pl/138945,polska-firma-zrobila-w-rok-to-czego-resort-morawieckiego-nie-zrobil-do-dzis-ich-technologia-pomaga-walczyc-ze-smogiem (dostęp: 20.06.20).

Blank S. (2010), Why Startups Are Agile and Opportunistic-Pivoting the Business Model, www. steveblank.com (dostęp: 25.06.2018).

Ecobins, https://mamstartup.pl/startupy/1060/ecobins (dostęp: 23.06.2018).

http://sense-monitoring.com/ (dostęp: 25.06.2018).

Słownik portalu Prawo Podatkowe, www.prawo-podatkowe.pl/finansowe/innowacje-technologiczne (dostęp: 19.06.2018).

Startup Wrocław, portal miasta Wrocław, https://www.wroclaw.pl/startupy (dostęp: 26.06.2018).

Trębacz I. (12.03.2018), Ledowa płynność ruchu, https://www.agh.edu.pl/blog-naukowy/info/article/ledowa-plynnosc-ruchu/ (dostęp: 25.06.2018).

Ekonomia — Wroclaw Economic Review 24/3 (2018)

(C) for this edition by CNS 